\title{
The Indiciary Paradigm as Methodology for Researches in Brazilian History of Communication
}

\author{
By Hérica Lene ${ }^{*} \&$ Francisca da Silva ${ }^{ \pm}$
}

\begin{abstract}
This article aims to address the indiciary paradigm as a methodology for research on the History of Media understanding it as part of a broader field: History of Communication. In this sense, we follow the characterization made by Ana Paula Goulart Ribeiro and Micael Herschmann (2008) on the field of historical studies of Communication in terms of methodology and research. The authors emphasize the historiographic analysis of the media of communication is relegated still as low priority. Although the interest in historical themes of Communication has been presenting in the last years as a growing trend in both Communication and History. As an example of the application of the scientific method of indicial studies in this area, we analyze the work Cultural History of the Brazilian Press - 1800-1900 (2010) by the researcher Marialva Barbosa. The indiciary paradigm has been created by Italian historian Carlo Ginzburg based on the book Myths, Emblems and Signs (2009), in which he presents the paradigm of index knowledge inspired by Sigmund Freud, Sherlock Holmes, art critic Morelli among others.
\end{abstract}

Keywords: communication, history, history of media, indiciary paradigm, microhistory.

\section{Introduction}

The field of Communication studies (mainly journalism) shares with History a deep link. Historians use the news records to elaborate their narratives, as one of their sources, and the communicologists use the historical knowledge in the development of the area researches.

The History of Communication in Brazil has been consolidating itself as a fertile area in researches, especially in this century. In mapping this field, Ana Paula Goulart Ribeiro and Micael Herschmann (2008, p. 13-26) record that the Communication in Brazil suffers from "presentism," since most of the research carried out in the country privileges aspects and problems related to contemporaneity: studies about postmodernity, globalization, new technologies, etc.

The authors emphasize the historiographic analysis of the Communication or the Medias of Communication are still relegated as low priority. Although the interest in historical themes of Communication has been a growing trend for both Communication and History in the last years.

In the interface of these two areas, the proposal of this article is to approach the indiciary paradigm as methodology to researches of Media History or Press History. We understand both as part of a broader field, which is History of Communication. The main question that instigates us is if indiciary paradigm can serve as a methodology for the historical studies of the communicational field.

\footnotetext{
*Professor, Federal University of Recôncavo da Bahia (UFRB), Brazil.

${ }^{ \pm}$Professor, University of Vila Velha (UVV), Brazil.
} 
The indiciary paradigm has been addressed specially in the Microhistory field. This article aims to demonstrate this methodology as suitable for History of Communication researches.

In the development of this approach, from an essay perspective, we called on the theoretical contributions from the two areas: Communication and History. This article has three parts: The first one in which the definition of the field of History of Communication is discussed; a second on indiciary paradigm research methodlogy and a third in which we analyze the application of indiciary paradigm in the work "Cultural History of Press-Brazil 1800-1900" (2010), by Marialva Barbosa.

\section{Literature Review}

The field of Communication has as one of its areas of research the studies of the History of Communication. Before thinking how the indiciary paradigm is suitable in such studies, it is important to better define the concept of the History of Communication.

In the article "History of Communication in Brazil: a field under construction," Ribeiro and Herschmann, organizers of the work "Communication and history: interfaces and new approaches" (2008), help us in this sense.

The authors, in seeking to characterize the field of historical studies of Communication in terms of methodology and research, emphasize that History of Communication and History of the Media (or the Press) are not exactly the same thing.

Communication is a broad concept, which can encompass all forms of social interaction, including interpersonal communications. If we consider communication as the production of socially shared meanings, the concept is almost confused with that of language.

In addition to the changes in the media itself, the History of Communication would encompass a range of other possibilities (study of the transformations of oral systems, fashion, architecture, etc.) and would almost be confused with the History of the Culture (Ribeiro \& Herschmann, 2008, p.16).

On the other hand, Mass Media does not constitute an abstract concept. Media means technologies, which has been developing and gaining new uses in certain historical contexts. It is associated with life styles and specific social organizations. Its appearance - beginning with the press - came about with modernity, with the consolidation of a whole set of institutions and forms of social organization (such as nation-states, market growth, industrialization, urbanization, secularization) and with the so-called acceleration of history (social dynamics marked by speed).

The authors emphasize that we can think of the History of the Media as part of a discipline or field of broader studies: a Cultural History or a History of Communication. In Brazil, professionals from different disciplinary fields like historians, social scientists and communicologists (journalists, publicists or other communication scholars) have developed the studies of History of Communication.

So how can indiciary paradigm serve as a useful methodology for studies in this field? We propose to discuss it in the next section. 


\section{Methodology}

How can we define the indiciary paradigm or the evidential paradigm? The researcher who works in the perspective of the evidence-based or indicial studies follows in search of the vestiges, signs and symptoms of the marks in the attempt to unravel the historical events. This type of scientific methodology is included in the microhistory and uses the same devices as the doctor when analyzing the patient and trying to discover the disease or the psychoanalyst who wants to unravel the traumas and access the unconscious.

Márcia Rodrigues (2006, p. 5) in the book "Exercises of Indiciary Paradigm" explains that well-known authors (such as Michel Foucault, Walter Benjamin, Gilberto Freyre, Lucien Febvre, Fernand Braudel, Mikail Bakhtin, Robert Darton, Peter Burke and Carlo Ginzburg, among others) wrote works marked by the appreciation of the details and the conciliation between rationality and sensitivity. They carried out in them a detailed and an exhaustive research revealing a detective character.

The guiding thread for the different works of these thinkers is the indiciary research based on the investigation of political, economic and social microstructures, everyday aspects and social intimacy, small events in history (Rodrigues, 2006).

The indiciary research uses, among other techniques, the method developed by the Italian theorist Carlo Ginzburg based on studies performed by Giovanni Morelli at the end of the 19th century. Morelli's goal was to identify the falsifications of famous paintings using less negligible details and less influenced by the characteristics of the school to which the painter belonged, such as the ear lobes, the nails, the shapes of the feet and the fingers (Ginzburg, 1989, p. 143-144).

According to Ginzburg, Morelli's books are unusual in relation to other art historians because they have illustrations of fingers, ears and minute features that identify a particular artist similar to a criminal identified by his fingerprints. "Any museum of art studied by Morelli immediately acquires the appearance of a criminal museum" (Ginzburg, 1989).

Castelnuovo, quoted by Ginzburg (1989), brought Morelli's evidential method closer to that attributed to Sherlock Holmes by its creator, Arthur Conan Doyle. The art connoisseur, he remarks, "resembles the detective who discovers the perpetrator of a crime (or the artist behind a painting) on the basis of evidence that is imperceptible to most people" (Ginzburg, 1989, p. 97-98).

For Ginzburg (1989), modern psychology would be at Morelli's side because our little unconscious gestures reveal our character more than any formal attitude. According to Ginzburg, Freud identified himself as a Russian art expert, Ivan Lermolieff, in his essay "The Moses of Michelangelo" (1914), where he referred to the method used by Morelli.

Freud, quoted by Ginzburg (1989), stated that his method is closely related to the technique of medical psychoanalysis, which also penetrated into hidden things through elements that are not noticed or covered, what he called the "debris" or "refuse" of our observation.

Ginzburg summarizes that one can speak of an indiciary or divinatory 
paradigm, according to the forms of knowledge, to the past, the present or the future and based in the medical semiotics (diagnostic and prognostic).

He further emphasizes this is the method not only used and accepted by society and physicians, by identifying the disease through symptoms, but also in one of the oldest gestures of the intellectual history of mankind by the hunter "squatting in the mud, who scrutinizes the tracks of the prey" (Ginzburg, 1989, p. 154).

\section{Results}

The production in History of Communication in Brazil has as one of its main characteristics the predominance of monographic researches, focusing on very specific subjects (a journal, for example) or in a certain period (in general, not very extensive), as mapped by Ribeiro and Herschmann (2008, p. 18-23). However, they point out that there must also be synthesis works that systematize logically the knowledge accumulated in the specific researches and can function as a subsidy for the development of new investigations.

In this sense, the reference work is Nelson Werneck Sodré's book "History of Press" first published in 1966. In addition to Juarez Bahia's book, "Newspaper, History and Technique: history of the Brazilian Press" (1990), only recently during the celebration of 200 years of the Brazilian press new books have been published by Marialva Barbosa (2007 and 2010) and by Richard Romancini and Cláudia Lago (2007).

In this article, we opted for an analysis of one of Marialva Barbosa's recent work. She researches the interconnection between the History and the Communication. In her work "Cultural History of the Press - Brazil 1800-1900" (2010), the researcher makes a careful and detailed investigation, starting from the arrival of the royal family in the Brazilian territory as they were escaping from the imminent invasion of Napoleon Bonaparte to Portugal.

They had inaugurated the press in Brazil more than 300 years later - since Johannes Gutenberg created the mobile type press in the middle of the fifteenth century in the Mainz, Germany, being rapidly expanded throughout Europe and even to Mexico a few years later (Giovanini, 1987).

The foundation of the Royal Printing in Brazilian land brought to the country the first official newspaper called "Gazeta do Rio de Janeiro" created on September 10, 1808. The press arrived in Brazil amidst a context of controversy because three months before another newspaper called "Gazeta Braziliense," an underground and an enemy of the Crown journal produced in London by Hipólito da Costa, was already circulating in Brazil.

Marialva Barbosa's investigative trajectory in this work ends at the beginning of the 20th century, in the first decades of 1900, when avid readers arise for sensational news, especially related to crimes, an even more striking feature in the contemporary press.

What is obvious in the introduction of the book is the methodology adopted by the author, which is implicit in the language used throughout the course of 
the work. Already in the first paragraph, she invites the reader: "History exists only in the present because the past has inscribed, in our here and now, multiple traces indicating the existence of this past" (Barbosa, 2010, p. 11).

The author further reinforces the need for this investigative pursuit by inviting the reader to "follow these clues to reinterpret the times of yesteryear trying to capture the spirit of other times." Then she emphasizes, "It is up to the historian to follow traces left in the present, walking through these traces towards the images of the past" (Barbosa, 2010).

Barbosa believes the press is also lavish in self-referencing because it produces texts that speak of the daily life and others that leave clues about its relations with the instances of power. Behind printed letters, photos and published illustrations, it is possible to trace the whole circuit of communication. She asks, "what were these publications, who wrote in those newspapers and what was writing?" She adds, "above all, what interpretations did this anonymous reader, who gradually, by the indications that a closer look can follow, becomes an illustrious known?" (Barbosa, 2010, p. 11).

For her, to write about the history of the press is certainly not to align facts and dates, names, nor to highlight the characters that have become singular in the constructions generated in the past for the future and that, most of the time, are tributary of the strategies of power (Barbosa, 2004).

According to Marialva apud Certeau (1982), building the history of the press requires making the same move as "writing history." It is to perceive history as a complex process, in which social, cultural relations, speeches and non-sayings are been engendered. It is up to the historian to ask for the silences and to identify in what has not been said a reason of an often-political nature. "Thinking historically presupposes contextualizing social spaces in a chain of facts, events, occurrences, and customs, institutions that conform as a flow before and after" (Barbosa, 2007).

When speaking particularly of a history of the press, Barbosa emphasizes that one must consider the notion of system, the very core of communicational relations. Thus, to speak of the history of the press is to talk about communication processes and the intricate relationships that develop around the communication system (Barbosa, 2007).

It was about the producers of the text and the different forms of appropriation of the messages by the public. It referred to the production. In what way or how and for whom it had been produced and what consequences this production had brought to society. Barbosa (2004) adds, "It is also to refer to the way in which the public reacted to those messages and to perceive how they carried out plural readings or interpretations."

For Barbosa (2004), the theory of history is a fundamental field for journalism studies because history cares about the reasons, the causes and the whys. To consider history is not necessarily to carry out historical studies, but to use the theory of history to undertake analysis. In this sense, she emphasizes that the main postulate of historiography refers to the question of interpretation. She explains: "It is not a question of recovering what actually occurs (because it can never be recovered), but interpreting - based on the subjectivity of the researcher - 
the reasons for a certain social action" (Barbosa, 2005a).

\section{Discussion}

In analyzing the work Cultural History of the Press - Brazil 1800-1900 (Barbosa, 2010) we find that the author traverses the same path as the indiciary paradigm researchers, that is, her research results from the articulation of principles and heuristic procedures centered on "details, marginal data, residues taken as clues, signs, traces, symptoms - according to psychoanalytic terminology."

Rodrigues (2006, p. 5) defines that the clues would be the official and the extra-official documents, secondary and voluntary sources, that is, those intentionally sought by the researcher. If they are subject to discourse, semiotic or symptomatic analysis sometimes they can reveal much more than a witness. She further clarifies that other sources can help in this process; those invited to witness in the construction of historical narratives, involuntary sources, found by chance, unintentionally and that sometimes insist and intrude on research.

In this case, the researcher uses the combination of reason and sensitivity so the sources hear and argue with creativity, intelligence and consistency, considering the faulty acts, metaphors, metonymy and displacements in documentary analysis (Rodrigues, 2006, p. 6).

The method that unites reason and sensibility was present throughout Marialva Barbosa (2010, p. 43-55) investigative research, when she reconstructed the stories of the 1821 newspaper, the "Maranhão Conciliator," especially in the chapter "A history by the margins." She observed the handwritten notes of anonymous readers left in editions of the newspaper in microfilms consulted by the author in the National Library (Rio de Janeiro).

Then, in the chapter "The Newspapers and the World of Slaves," Barbosa (2010) was able, through the sensitivity and analysis of published material and engravings, to capture the meaning of this pre-abolitionist period when slaves began to constitute themselves as readers and anonymous participants in Brazilian political life.

For the author to speak of the relation of the press and the world of the slaves is to show the way the periodicals refer to them or to highlight the discourses more or less favorable to the abolition. In addition, it was important to recognize that it has influenced their lives.

This connection made them actors and subjects of history by the way they appeared in the newspapers. Their marks and wounds were being exposed and printed in the same newspapers where there were descriptions of advertisements in search of the rebels' slaves who repeatedly escaped from captivity. According to the author, "these journals were being divided with more or less fervor in favor of their cause" (Barbosa, 2010, p. 80).

The researcher says that in the periodicals and magazines of the period repeatedly appeared the faces and the bodies of the slaves. "Amorphous mass, presented in an undifferentiated way as something, men of color, blacks or 'pieces,' as they were mentioned in the announcements." She adds: (...) "the 
slaves live in cities where multiple sociabilities allow mixtures that certainly make them aware of what those publications talk about."

Her work made it clear from the expressions and from her narrative that the author (Barbosa, 2010) was moved by this situation of indifference to the slaves and that she had used the text to denounce these unfair conditions in a very sensitive way.

Through the clues, Barbosa (2010) discovered the world of the slaves and realized they had access to reading. For her, there were signs that many slaves could read or at least "listen to the news that echoed through the streets, squares and big houses." These indications were in several situations described by the author.

From the proximity that some of the slaves experienced in the home of their owners - exercising domestic activity or even as a hard worker slave leaded us to seek indications of their readings in different levels. The slaves observed in the city since they circulated through the streets, squares and alleys, or in the kind of activity, they had carried out. It allowed us to say that it was not only passively that they appeared in the pages of publications.

The occasional sale of periodicals, such as the "Gazeta de Notícias," began in 1875 with the shrill cry of the slaves' sons who delivered the new publication on the streets of Rio de Janeiro (Barbosa, 2010, p. 80).

Marialva Barbosa (2010) also noted that when the slaves were not able to read still some of them had a degree of understanding among those who lived in the capitals. As matter of fact, in the 1870 s society there were not only masters and slaves as a simplistic interpretation might suppose. She reinforced "there were slaves for work or for rent, and freedmen exercising specialized professions, such as carpenters and masons, which certainly made them deal at least with numerical codes."

The author also mentioned some freedmen handled typographic presses, which made typographic letters part of everyday work. There were also the national free workers exercising the most diverse professions, such as artisans, traders, employees of the textile industries and the European immigrants. She stated, "In the universe of large cities, the slave contingent was representative."

The researcher revealed that the voices of the slaves and their thoughts, produced by the "understanding of the world they effectively exercised," figured in an evident silence difficult to overcome. She added the difficulties faced by them, and continuously highlighted aspects related to indiciary paradigm, such as the expressions "evident silence" and "evident traces." (Barbosa, 2010).

The slaves were not producers of texts, but they were communicating through the oral forms and they were always silent from the point of view of the documents' productions. For this reason, the author explains: "they did not leave the evident traces of how they knew the printed documents and how they carried out their readings and appropriations" (Barbosa, 2010, p. 84).

The indiciary paradigm technique was the similar to the one used by the hunters at the time of the first human groupings, as described by Ginzburg apud Rodrigues (2006, p. 10), whose investigation was based on clues, mud tracks, broken branches, dung acorns, tufts of hair, feathered tangles and stagnant odors. 
Barbosa (2010, p. 84) stated that only considering the "traces of the past as possible messages there will be historical awareness in the present that is available to visualize the readings and the interpretations, so it will be possible to recover those voices."

Barbosa defended that the printed papers had an import role in the forms of understanding the world in contact with the society. "It takes a predisposition in the present time to think of the slaves not only as objects, but as historical subjects who lived in a world of multiple voices" (Barbosa, 2010, p. 84).

According to the author, the existence of slaves capable of reading is an event of the historical past forgot for decades. "Always contained in the present by the ruses of the memory, the past makes it possible at some point in our historical consciousness to remember what had been systematically forgotten" (Barbosa, 2010, p. 84).

The researcher points out that the memory is a concept resulting from the disputes and the dialogues. Since the nineteenth century, many authors have attempted to account for the complex theorizing around various fields of knowledge. "History, on the other hand, is defined as being a field of knowledge, a discipline, a practice, a writing with a symbolizing function that allows society to situate itself, making room for the past" (2005b, p. 107).

Therefore, speaking of the memory is to refer to four fundamental postulates: memory is action of the present; it necessarily provokes the idea of disputes by meanings; it is a product of the dialectic to remember and to forget, being, therefore, place of choices; and finally, it is a project towards a desired future (Barbosa, 2005b).

Morel, quoted by Barbosa (2010, p. 86), noticed the production of the slaves and freed-slaves in the Brazilian historiography. This was possible by making a historical survey that searched to understand the degree of literacy or reading of the slaves in the nineteenth-century. She mentioned the case of the young slave Eduarda who left marks in the printed-paper.

Barbosa described the slave Eduarda as wandering on the street at the morning of February 11, 1886, "with bruises and open wounds on her face and arms, visible marks of the torture imposed on her by her owner." According to Barbosa (2010), Eduarda was approached by a woman who dissuaded her from going to the Chief of Police, advising her to go instead to the "Gazeta da Tarde" newsroom in the center of Rio de Janeiro, where she would be safer and she could have been heard. The newspaper was founded by the abolitionist leader José do Patrocínio in 1881 (Barbosa, 2010, p. 86).

According to Morel, cited by Barbosa (2010, p. 86), Eduarda and another slave received medical attention before they conducted them to the judge of the Second Civil Court. Patrocínio had publicized the events in the press. "Eduarda did not know how to read, but she was able to understand when the woman who approached her suggested that she should go to the newspaper office owned by José do Patrocínio." Barbosa emphasized the symbolism and the importance of the printed papers in this society, represented by the newspaper that would welcome her (Barbosa, 2010, p. 87).

The researcher pointed out also the case of the two slaves tortured to death by 
a wealthy woman and lover of a wealthy merchant. It had all the ingredients that might have interested the reader: "Torture against the defenseless, the situation of poverty and destitution of the victims and the mighty against the weak" (Barbosa, 2010).

Another interesting example mentioned by Barbosa (2010, p. 105-106) was the issue of October 15, 1887, in the Illustrada Magazine. The image reproduced a scene of the reading of the slaves. Under the caption, "a farmer also made a discovery that left him shocked! A slave read on the bed for his partners about an abolitionist speech by Counselor Dantas." In another situation, a rural scene appeared where eleven slaves formed a circle: in the center, one holding a newspaper. The name of the periodical was "O Paíz." Holding the first page, one read. The others - seven men, two women and one child - were gawking at him. "They leaned on the hoe and made absolute silence. They listened carefully to the words of the printed paper invading the oral world" (Barbosa, 2010).

The scene indicated that despite the reiterated silence of decades about the practices of these subjects, a trace appeared showing that there was much more correlation between the press and slavery than we might at first have supposed (Barbosa, 2010, p. 106).

Ginzburg (1989, p. 177) had stated, "if the reality is opaque, there are privileged zones - signs, clues - that enable us to decipher it." In these analyzed examples of the work of Marialva Barbosa, it was clear that the author used indiciary paradigm to uncover the nebulous zones, either by using the information on the margins of the periodicals or by reconstructing their important role in the period of the Brazilian Empire.

Then, it was possible to find out the participation of the slaves in the literate world through readings. In addition to the discovery of these newspapers as a source of complaints of ill-treatment of the slaves. Through the association "sensibility and reason" that the indiciary paradigm presents, it is possible to get closer to our historical past in a more vibrant and true way.

The researcher ended her book by stating, "the reader was a fundamental part in the construction of this text. We searched to follow its tracks, in 'traces' that time is gradually erasing" (Barbosa, 2010, p. 253). She further reinforced this idea, adding, "recovering the face of past readers was no easy task. Also they left innumerable 'marks' that could refer to the forms related to the texts and, above all, to the understanding they had and produced from those texts" (Barbosa, 2010, p. 253-254).

These marks would have been "written in many ways and through many gestures" (Barbosa, 2010). Then she complemented with the type of source she searched. It could have been in the handwritten form, in the margin of the publications, indicating an attentive reading. "A reading backward and forward," in the attempt to unveil concepts and to understand the world, but it could also be "in the silence" performed by some readers of the past. "Multiple and plural readings gave life to the periodicals that appeared and disappeared throughout the nineteenth century in Brazil (Barbosa, 2010). 


\section{Conclusion}

The field of the History of Communication in Brazil has been consolidating itself as a fertile area in researches, especially in this century. In the interface of the two areas - Communication and History - the proposal of this article was to approach the indiciary paradigm as a methodology for the researches of the History of Press or Media, understanding both as part of a broader field: History of Communication.

The researcher who works in the perspective of the indicial studies follows in search of the vestiges, the signs, the symptoms or the marks in the attempt to unravel the historical events.

In this approach, we took as an example the work "Cultural History of the Press - Brazil 1800-1900," by Marialva Barbosa (2010), whose analysis showed its proximity to the Carlo Ginzburg's indiciary paradigm. We have verified that the indiciariary paradigm can be useful to the investigations of this field.

The analysis showed that the author traverses the same path as the indiciary paradigm investigators. This kind of research results from the articulation of heuristic principles and procedures centered in details, marginal data, and residues taken as clues, signs, traces and symptoms.

The association of the "sensibility and the reason" by the indiciary paradigm enriches the historical studies of Communication, since it allows a greater approximation with the historical past, in a more vibrant and true way.

\section{References}

Bahia, J. (1990). Newspaper, history and technique: history of the Brazilian Press. Jornal, história e técnica: história da imprensa brasileira. São Paulo: Ática.

Barbosa, M. (2010). Cultural History of the press - Brazil 1800-1900 História Cultural da Imprensa - Brasil 1800-1900. Rio de Janeiro: Mauad X.

Barbosa, M. (2007) Cultural History of the press - Brazil 1900 - 2000. Rio de Janeiro: Mauad X.

Barbosa Marialva. The owners of Rio - Press, power and public. Os donos do RioImprensa, poder e público. Rio de Janeiro: Vício de Leitura, 2000, 257p.

Barbosa, M. (2005a). What history can bequeath to journalism studies. Revista do Programa de Pós-Graduação em Comunicação - UFF, 12, 51-63.

Barbosa, M. (2005b). Journalism and the construction of a memory for your history. In: Bragança, A., \& Moreira, S. V. (Eds.), Comunicação, acontecimento e memória (Communication, event and memory), pp. 102-111. São Paulo: Intercom.

Barbosa, M. (2004). How to write a history of the press? Work presented at the WG of History of Journalism at the 2nd National Meeting of the Alfredo de Carvalho Network, Florianópolis, April 15-17, 2004.

Certeau, M. de. (1982). The writing of the history. Rio de Janeiro. Forense Universitária.

Giovanini, G. (1987). Evolution in Communication - from Flint to Silicon (2nd edn.). São Paulo: Ed. Nova Fronteira.

Ginzburg, C. (Edn.) (1989). Roots of an indiciary paradigm. In: Ginzburg, C. Myths, emblems and signs - Morphology and History, pp. 143-171. São Paulo: Cia das 
Letras.

Ribeiro, A. P. G., \& Herschmann, M. (Edn.) (2008) Communication and history: interfaces and new approaches. Rio de Janeiro: Mauad X.

Rodrigues, M. (Edn.) (2006). Exercises of indiciarism. Rumos do História Collection. Vitória: Program of Social History of Political Relations of UFES.

Romancini, R., Lago, C. (2007). History of journalism in Brazil. Florianópolis: Insular.

Sodré, N. W. (1966). The history of the press in Brazil. Rio de Janeiro: Civilização Brasileira. 
